\title{
"KEARIFAN LOKAL SUKU TENGGER DALAM ADAPTASI PERUBAHAN IKLIM DAN PENGARUHNYA TERHADAP PENINGKATAN PRODUKSI TANAMAN KENTANG"
}

\author{
"Local function of success in the adaptation of climate change and its effect on \\ increasing potato plants production"
}

Totok Fermansah $^{1}$, Wenny Mamilianti ${ }^{1}$

Jurusan Agribisnis Fakultas Pertanian Universitas Yudharta Pasuruan e-mail: ${ }^{1}$ totokfermansah@gmail.com, ${ }^{2}$ wennymfp@yudharta.ac.id

\begin{abstract}
ABSTRAK
Beberapa penelitian menyebutkan alokasi input petani dipengaruhi oleh adanya perubahan iklim. Oleh karena itu permasalahan penelitian ini fokus pada (1) Bagaimana adaptasi suku Tengger dalam perubahan iklim?, (2) Bagaimana pengaruh adaptasi perubahan iklim masyarakat suku Tengger terhadap produksi tanaman kentang? Tujuan penelitian ini adalah : (1) Mendiskripsikan adaptasi suku Tengger dalam perubahan iklim. (2) Menganalisis pengaruh adaptasi perubahan iklim terhadap produksi tanaman kentang. Penelitian ini adalah penelitian survey yaitu pengambilan data dilakukan langsung pada sampel sebagai responden melalui kuisener. Penelitian dilakukan di Kec.Tosari Kab.Pasuruan dan sampel adalah petani Suku Tengger di Ds. Wonokitri Kec.Tosari Kab.Pasuruan. Metode analisis yang digunakan adalah tabulasi data, score dan coding, serta pendekatan fungsi produksi Cobb Douglas. Hasil penelitian menunjukkan bahwa tindakan adaptasi yang paling banyak dilakukan secara turun temurun adalah penghematan penggunaan air, penggunaan pupuk kandang, pengolahan lahan berlawanan kontur, penggunaan irigasi yang baik, penggunaan pestisida kimiawi, peningkatan intensitas penyiangan gulma, penyiapan benih yang baik, penanaman awal musim hujan, perubahan wakyu tanam, penggunaan jarak tanam rekomendasi, mencari informasi perubahan iklim, penanganan hasil panen dengan meminimalkan susut hasil, pengurangan luas lahan garapan, dan berpindah dari lokasi berisiko tinggidampak perubahan iklim. Hal ini dilihat dari prosentase terbesar yaitu 80-100\%. Dan hasil kedua menunjukkan bahwa benih, urea, tenaga kerja dan dummy penerapan adaptasi perubahan iklim merupakan variable yang berpengaruh positif nyata terhadap produksi. Sedangkan penggunaan pestisida merupakan variable yang berpengaruh negative nyata terhadap produksi. dan variable yang tidak berpengaruh nyata adalah lahan, penggunaan pupuk SP, NPK, dan pupuk kandang.

Kata Kunci : kearifan lokal, adaptasi, produksi kentang, perubahan iklim, stochastic production frontier.
\end{abstract}

\section{ABSTRACT}

Some studies say the allocation of farmers' inputs is influenced by climate change. Therefore the problem of this research focuses on (1) What is the adaptation of the Tengger tribe in climate change?, (2) What is the effect of the climate change adaptation of the Tengger tribe on the production of potato crops? The purpose of this study are: (1) Describe the adaptation of the Tengger tribe in climate change. (2) Analyzing the effects of climate change adaptation on potato crop production. This research is survey research, that is data collection is done directly on the sample as 
respondents through questionnaires. The study was conducted in the Sub-district of Tosari Regency and the sample was the Tengger Tribe farmers in Ds. Wonokitri Kec. Tosari Kab. Pasuruan. The analytical method used is data tabulation, score and coding, and Cobb Douglas production function approach. The results showed that the most adaptation actions carried out from generation to generation were saving water use, using manure, processing land opposite contours, using good irrigation, using chemical pesticides, increasing the intensity of weed weeding, preparing good seeds, planting the early wet season, changes in planting time, use of recommended spacing, seeking information on climate change, handling crop yields by minimizing yield losses, reducing the area of cultivated land, and moving from high-risk locations to climate change impacts. This is seen from the largest percentage of $80-100 \%$. And the second result shows that seeds, urea, labor and dummy application of climate change adaptation are variables that have a real positive effect on production. While the use of pesticides is a variable that has a significant negative effect on production. and variables that have no significant effect are land, use of SP fertilizer, NPK, and manure. Keywords: local wisdom, adaptation, potato production, climate change, stochastic production frontier.

\section{PENDAHULUAN}

Perubahan iklim sudah dirasakan di Indonesia sejak abad 19. Pola perubahan musim mulai tidak beraturan sejak 1991 yang mengganggu swasembada pangan nasional. Beberapa peneliti menyatakan bahwa perubahan iklim terjadi pada abad 19 yang ditandai dengan adanya peningkatan suhu, dan perubahan cuaca yang ekstrim. Wang et al (2010) menjelaskan bahwa perubahan suhu di Cina 20 tahun berturut-turut terjadi kenaikan suhu pada tahun 1986-2005. Intergoverment Panel On Climate Change (IPCC, 2013) melaporkan bahwa kenaikan suhu global rata-rata $0,85^{\circ} \mathrm{C}$ terjadi dari tahun 1880 sampai 2012, dan diprediksi terus berlanjut $1,5^{\circ} \mathrm{C}-2,5^{\circ} \mathrm{C}$ sampai tahun 2050.
Isu pentingnya dampak perubahan iklim pada sektor pertanian adalah penurunan produksi yang disebabkan oleh serangan hama penyakit, jenis hama penyakit yang beragam, kualitas tanah yang menurun, kekeringan dan bencana alam. Penurunan produksi pertanian akibat perubahan iklim ini telah diteliti oleh beberapa peneliti yang menjelaskan bahwa perubahan iklim menurunkan produksi pertanian. Salwati (2012) menjelaskan bahwa peningkatan suhu udara dan penurunan curah hujan secara bersama-sama mengakibatkan penurunan perkembangan tanaman pada setiap fase yang mengakibatkan penurunan hasil kentang. Salinger et al (2000) menjelaskan bahwa suhu rendah dalam waktu yang lama memperpendek periode vegetasi dan menghambat produktivitas 
tanaman hortikultura di Negara tropis dan sub tropis. Hatfield et al (2011) menjelaskan bahwa di USA bagian selatan dengan peningkatan suhu akan menurunkan hasil kedelai sampai $24 \%$.

$$
\text { Proses adaptasi merupakan }
$$
serangkaian proses dari manusia untuk melakukan penyesuaian diri atau memberi respon terhadap perubahan lingkungan fisik maupun sosial yang terjadi secara tidak menentu. Menurut Sulistiono R dan Soemarmo (2011) adaptasi terhadap perubahan iklim harus segera dilakukan, jika tidak dunia akan mengalami penurunan produksi pangan hingga $7 \%$. Namun dengan adaptasi yang berkelanjutan tentunya memerlukan biaya yang tinggi misalnya dengan pembangunan irigasi, penggunaan input produksi tambahan, langkah konservasi dan sebagainya.

Masyarakat Suku Tengger adalah masyarakat yang selalu menjunjung kearifan lokal yang diturunkan secara turun-temurun dari leluhurnya. Kearifan lokal tersebut antara lain dalam hal bercocok tanam dan kelestarian lingkungan. Namun 10 dekade terakhir seiring pergantian penguasaan lahan dimana penguasaan lahan beralih ke ahli waris pemahaman akan kearifan lokal mulai ditinggalkan, hal ini dikarenakan adanya modernisasi informasi dan budaya yang dibawa masyarakat pendatang baik itu wisatawan atau pendatang yang menetap tinggal di wilayah Tengger.

Dataran Bromo Tengger Semeru dimana masyarakat Suku Tengger bermukim adalah kawasan yang subur karena di lereng gunung Merapi. Berbagai tanaman tumbuh subur utamanya tanaman sayuran. Dengan adanya perubahan iklim yang dirasakan menunjukkan penurunan produksi sayuran. Produksi kentang ditahun 1990 an mencapai 40 ton/ha, namun sekarang hanya mencapai 16 ton/ha. Penurunan produksi ini jika tidak segera ditangani terutama dengan strategi adaptasi petani maka tentunya produksi pertanian akan terus menurun apalagi ada indikasi perubahan perilaku petani dalam penerapan kearifan lokal. Penurunan produksi ada kaitannya dengan efisiensi teknis dalam penanganan usahatani. Dimana efisiensi teknis berhubungan dengan alokasi sumberdaya dan faktor sosial ekonomi. Menurut Otitoju M.A dan Enete, A.A (2014) dalam penelitiannya menjelaskan bahwa perilaku adaptasi petani terhadap perubahan iklim mempengaruhi efisiensi usahatani di Nigeria. Masalahnya adalah kesadaran adanya perubahan iklim hanya dipahami oleh sebagian masyarakat Tengger dan 
sebagian lagi masih menanggapinya dengan sikap yang biasa saja. Hal ini terbukti dengan adanya perubahan perilaku di kalangan beberapa petani yang mengabaikan kearifan lokal. Oleh karena itu strategi adaptasi terhadap perubahan iklim sangatlah penting segera dilakukan khususnya di daerah pertanian yang subur di kawasan Bromo Tengger Semeru. Mengingat daerah tersebut merupakan sentra produksi sayuran Jawa Timur.

Penelitian tentang strategi adaptasi terhadap perubahan iklim sangatlah penting dilakukan. Sejauh ini sudah banyak penelitian tentang bagaimana petani melakukan strategi adaptasi terhadap perubahan iklim. Namun studi atau penelitian yang menginvestigasi dan mengidentifikasi perilaku indegenous knowledge atau kearifan lokal yang berupa adaptasi terhadap perubahan iklim belum banyak dilakukan baik di Indonesia maupun Internasional. Beberapa penelitian tentang indegenous knowledge atau kearifan lokal lebih fokus pada penelitian etnobotani dan kelestarian hutan. Penelitian atau investigasi terhadap pengaruh strategi adaptasi perubahan iklim terhadap efisiensi produksi dan inefisiensi teknis juga belum banyak dilakukan, kecuali yang dilakukan Otitoju M.A dan Enete A.A (2014).
Oleh karena itu, permasalahan dalam penelitian ini yaitu 1)Bagaimana adaptasi suku Tengger dalam perubahan iklim?. 2)Bagaimana pengaruh adaptasi perubahan iklim masyarakat suku Tengger terhadap produksi tanaman kentang?. Untuk memfokuskan penelitian agar pembahasannya tidak meluas, maka peneliti membatasi permasalahan dalam penelitian ini yaitu Penelitian ini hanya di fokuskan di Desa Wonokitri Kecamatan Tosari Kabupaten Pasuruan, serta Suku Tengger yang bermukim di daerah penelitian. Kearifan lokal yang dimaksud dalam penelitian ini adalah kearifan lokal menurut Purnomohadi 1985 dalam Nurrahim A, 2014 yang menjelaskan bahwa Kearifan lokal merupakan pengetahuan secara turun temurun yang dimiliki oleh masyarakat untuk mengelola lingkungan hidupnya.

\section{METODE PENELITIAN}

Lokasi penelitian in dilakukan di Desa Wonokitri, Kecamatan Tosari Kabupaten Pasuruan. Penentuan lokasi ini dilakukan secara purposive atau secara sengaja dengan pertimbangan desa wonokitri merupakan wilayah suku Tengger dan merupakan daerah sentra produksi kentang. Penelitian ini dilakukan 
selama tiga bulan, mulai bulan Mei sampai Juli 2018.

Data yang digunakan dalam penelitian ini berupa data primer dan sekunder. Data primer dikumpulkan melalui wawancara langsung sesuai pertanyaan yang telah disusun dalam bentuk kuisener kepada petani dan beberapa sumber informasi kunci yang ada. Kemudian observasi yang dilakukan secara langsung di daerah penelitian. Data sekunder diperoleh dari literature-literatur yang relevan, penelitian terdahulu dan instansi yang terkait dalam penelitian ini, yaitu kantor Kecamatan Tosari Kabupaten Pasuruan dan atau melalui website BPS Kabupaten Pasuruan. Sampel dalam penelitian ini adalah petani kentang pada waktu dilakukan penelitian. Teknik pengambilan sampel dalam penelitian ini menggunakan teknik multi-stage cluster sampling, yaitu proses pengambilan sampel yang dilakukan melalui dua tahap atau lebih.

Metode yang digunakan dalam penelitian ini adalah metode analisis diskriptif tabulatif, $\quad$ yaitu mengelompokkan jawaban dari sample, dilanjutkan dengan sistem coding untuk menjawab permasalahan pertama, sedangkan ūntuk menjawab permasalahan kedua menggunakan metode pendekatan fungsi produksi Cobb-Douglas dalam bentuk logaritma natural. Adapun model tersusun berdasarkan spesifikasi fungsi produksi Cobb-Douglas dalam bentuk logaritma natural adalah :

$$
\begin{gathered}
\ln P d=\beta_{0}+\beta_{1} \ln L h_{\mathrm{i}}+\beta_{2} \ln B n_{\mathrm{i}}+\beta_{\mathrm{a}} \ln U r e a_{\mathrm{i}}+\beta_{4} \ln S P_{\mathrm{i}}+\beta_{5} \ln N P K_{\mathrm{i}}+\beta_{7} \ln P k d_{\mathrm{i}} \\
+\beta_{6} \ln T K_{\mathrm{i}}+\beta_{9} \ln P e s_{\mathrm{i}}+\beta_{7} D C C_{\mathrm{i}}+V_{\mathrm{i}}
\end{gathered}
$$

dimana :

$$
\begin{array}{ll}
\mathrm{Pd} & =\text { Jumlah produksi/output }(\mathrm{kg}) \\
\mathrm{Lh} & =\text { Luas lahan }\left(\mathrm{m}^{2}\right) \\
\mathrm{Bn} & =\text { Jumlah Benih }(\mathrm{kg}) \\
\mathrm{Urea} & =\text { Jumlah Urea }(\mathrm{kg}) \\
\mathrm{SP} & =\text { Jumlah pupuk SP }(\mathrm{kg}) \\
\mathrm{NPK} & =\text { Jumlah pupuk NPK }(\mathrm{kg}) \\
\mathrm{Pkd} & =\text { Jumlah pupuk kandang }(\mathrm{kg}) \\
\mathrm{TK} & =\text { Jumlah tenaga kerja }(\mathrm{HOK}) \\
\mathrm{Pes} & =\text { Jumlah pestisida }(\mathrm{lt})
\end{array}
$$


DCC = variabel dummy penerapan adaptasi oleh petani, bernilai 1 jika petani menerapkan langkah-langkah adaptasi secara baik, bernilai 0 jika petani tidak menerapkan atau menerapkan tidak sepenuhnya. Nilai ini diperoleh dari hasil wawancara dan kuisener dengan petani.

$\mathrm{i} \quad=$ Jumlah petani responden

$\beta_{0} \quad=$ Intersep

$\beta_{1}-\beta_{7}=$ koefisien parameter dugaan variabel/faktor produksi $\left(\beta_{1}-\beta_{7}>0\right)$

$\mathrm{V}_{\mathrm{i}}=$ Variabel acak, dimana variabel tersebut merupakan faktor eksternal (Iklim, serangan hama penyakit atau kesalahan dalam permodelan) sebarannya simetris dan menyebar normal $\left(V_{i j} \sim N\left(0, \sigma v^{2}\right)\right.$.

\section{HASIL DAN PEMBAHASAN}

Hasil identifikasi tindakan atau cara adaptasi terhadap perubahan iklim yang dilakukan oleh petani Tengger secara turun temurun ada 17, antara lain : penggunaan penghematan air, penggunaan pupuk kandang secara intensif, pengolahan lahan berlawanan kontur, penggunaan penutup tanah, penggunaan system irigasi dan drainase yang baik, penggunaan pestisida hayati, peningkatan intensitas penyiangan gulma, penyiapan benih/bibit yang baik dan teliti, penanaman pada awal musim hujan, penanaman tanaman penguat terasiring, penerapan system penanaman tumpang sari/tumpang gilir, perubahan waktu tanam, penggunaan jarak tanam rekomendasi, menghindari penanaman yang sama berturut-turut pada lahan yang sama, mencari informasi tentang varietas tahan hujan/kekeringan. perubahan iklim, penanganan hasil panen dengan meminimalkan kehilangan/susut hasil, pengurangan luas lahan.

Ada 9 tindakan adaptasi yang merupakan rekomendasi dari pihak eksternal antara lain dari pemerintah atau ketua kelompok tani yang sudah berpengalaman. Tindakan adaptasi tersebut antara lain penambahan luas lahan garapan, berpindah dari kegiatan bertani ke kegiatan berdagang, berpindah dari produksi tanaman sayuran ke produksi tanaman pangan atau ternak, lebih giat mencari pekerjaan paruh waktu diluar pertanian, berpindah dari lokasi berisiko tinggi terhadap dampak perubahan iklim, pengurangan penggunaan input kimiawi, penggunaan pestisida kimia, penggunaan varietas tahan hama penyakit, dan penggunaan 
Hasil penelitian tergambar pada tabel berikut

Tabel 11. Adaptasi petani terhadap perubahan iklim

\begin{tabular}{|c|c|c|c|c|}
\hline $\begin{array}{c}\text { No } \\
\text {. }\end{array}$ & Adaptasi & kategori & $\begin{array}{c}\text { Jumlah } \\
\text { petani }\end{array}$ & $\%$ \\
\hline \multirow[t]{2}{*}{1} & Penghematan penggunaan air & 1 & 28 & 80 \\
\hline & & 0 & 7 & 20 \\
\hline \multirow[t]{2}{*}{2} & Penggunaan pupuk kandang secara lebih & 1 & 35 & 100 \\
\hline & intensif & 0 & 0 & 0 \\
\hline \multirow[t]{2}{*}{3} & Penggunaan varietas tahan hama penyakit & 1 & 25 & 71 \\
\hline & & 0 & 10 & 29 \\
\hline \multirow[t]{2}{*}{4} & Penggunaan varietas tahan hujan/kekeringan & 1 & 7 & 20 \\
\hline & & 0 & 28 & 80 \\
\hline \multirow[t]{2}{*}{5} & Pengolahan lahan berlawanan kontur & 1 & 30 & 85 \\
\hline & & 0 & 5 & 15 \\
\hline \multirow[t]{2}{*}{6} & Penggunaan penutup tanah & 1 & 14 & 40 \\
\hline & & 0 & 21 & 60 \\
\hline \multirow[t]{2}{*}{7} & Penggunaan irigasi dan drainase yang baik & 1 & 31 & 88 \\
\hline & & 0 & 4 & 12 \\
\hline \multirow[t]{2}{*}{8} & Penggunaan pestisida hayati & 1 & 6 & 17 \\
\hline & & 0 & 29 & 83 \\
\hline \multirow[t]{2}{*}{9} & Penggunaan pestiisida kimiawi & 1 & 29 & 83 \\
\hline & & 0 & 6 & 17 \\
\hline \multirow[t]{2}{*}{10} & Pengurangan penggunaan input kimiawi & 1 & 0 & 0 \\
\hline & & 0 & 35 & 100 \\
\hline \multirow[t]{2}{*}{11} & Peningkatan intensitas penyianyan gulma & 1 & 35 & 100 \\
\hline & & 0 & 0 & 0 \\
\hline \multirow[t]{2}{*}{12} & Penyiapan benih / semaian yang lebih baik & 1 & 35 & 100 \\
\hline & dan teliti & 0 & 0 & 0 \\
\hline \multirow[t]{2}{*}{13} & Penanaman pada awal musim hujan & 1 & 35 & 100 \\
\hline & & 0 & 0 & 0 \\
\hline \multirow[t]{2}{*}{14} & Penanaman tanaman penguat terasiring & 1 & 33 & 94 \\
\hline & & 0 & 2 & 6 \\
\hline \multirow[t]{2}{*}{15} & Penerapan sistem penanaman tumpang sari/ & 1 & 21 & 60 \\
\hline & tumpang gilir & 0 & 14 & 40 \\
\hline \multirow[t]{2}{*}{16} & Perubahan waktu tanam & 1 & 28 & 80 \\
\hline & & 0 & 7 & 20 \\
\hline \multirow[t]{2}{*}{17} & Penggunaan jarak tanam rekomendasi & 1 & 35 & 100 \\
\hline & & 0 & 0 & 0 \\
\hline \multirow[t]{2}{*}{18} & Menghindari penanaman tanaman yang sama & 1 & 23 & 65 \\
\hline & berturut-turut pada lahan yang sama & 0 & 12 & 35 \\
\hline \multirow[t]{2}{*}{19} & Mencari informasi tentang perubahan iklim & 1 & 35 & 100 \\
\hline & & 0 & 0 & 0 \\
\hline \multirow[t]{2}{*}{20} & Penanganan hasil panen dengan & 1 & 35 & 100 \\
\hline & meminimalkan kehilangan/ susut hasil & 0 & 0 & 0 \\
\hline \multirow[t]{2}{*}{21} & Berpindah dari lokasi berisiko tinggi terhadap & 1 & 0 & 0 \\
\hline & dampak perubahan iklim & 0 & 35 & 100 \\
\hline
\end{tabular}


22 Pengurangan luas lahan garapan

23 Penambahan luas lahan garapan

$\begin{array}{ccc}1 & 35 & 100 \\ 0 & 0 & 0 \\ 1 & 7 & 20 \\ 0 & 28 & 80 \\ 1 & 5 & 14 \\ 0 & 30 & 86 \\ 1 & 5 & 14 \\ 0 & 30 & 86 \\ 1 & 9 & 25 \\ 0 & 26 & 75\end{array}$

Sumber : data diolah, 2018

Dari beberapa tindakan adaptasi yang dilakukan oleh Petani Tengger, terdapat keragaman hasil namun tindakan adaptasi yang telah dilakukan secara turun temurun masih diterapkan oleh penerusnya. Hal ini terbukti dari beberapa tindakan adaptasi turun temurun menunjukkan $80 \quad-100 \%$ petani melakukan yaitu penggunaan penghematan air, penggunaan pupuk kandang secara intensif, pengolahan lahan berlawanan kontur, penggunaan system irigasi dan drainase yang baik, peningkatan intensitas penyiangan gulma, penyiapan benih/semaian yang lebih baik dan teliti, penanaman pada awal musim hujan, penanaman tanaman penguat terasiring, perubahan waktu tanam, penggunaan jarak tanam rekomendasi, mencari informasi tentang perubahan iklim, penanganan hasil panen dengan meminimalkan susut/kehilangan hasil, pengurangan luas lahan garapan. Selain itu tindakan adaptasi turun temurun yang sudah ditinggalkan oleh petani Tengger dilihat dari persentase $(\%)$ terendah yaitu penggunaan pestisida hayati, hal ini dikarenakan petani sudah ketergantungan dengan pestisida kimia dan pengaruh modernisasi pada petani.

Sedangkan adaptasi rekomendasi yang dilakukan oleh petani Tengger yaitu penambahan luas lahan garapan, berpindah dari kegiatan bertani ke kegiatan berdagang, berpindah dari produksi tanaman sayuran ke produksi tanaman pangan atau ternak, lebih giat mencari pekerjaan paruh waktu di luar pertanian, dan penggunaan varietas tahan hujan/kemarau. Adaptasi rekomendasi tersebut hanya dilakukan oleh sebagian petani Tengger, hal ini disebabkan karena petani masih dalam tahap mencoba dan melihat hasilnya.

Analisis pada model produksi dan penggunaan input pada usahatani kentang dilakukan dengan menganalisis model produksi dalam ekonomi produksi dengan 
melihat berdasarkan kriteria ekonomi dan statistik. Secara keseluruhan model perilakunya menunjukkan hasil yang memenuhi kreteria baik secara ekonomi maupun statistik. Secara ekonomi tanda dan besaran pada setiap persamaan bisa menjelaskan fenomena yang ada. Nilai koefisien determinasi $\left(\mathrm{R}^{2}\right)$, nilai F-hitung dan nilai probabilitas $F($ Uji F) serta $\mathrm{T}$ - hitung dan probabilitas $\mathrm{T}$ (Uji-T) yang merupakan kreteria statistik secara keseluruhan juga menunjukkan hasil yang baik pada fungsi produksi yang diestimasi.

Secara statistik hasil analisis menunjukkan bahwa model yang dispesifikasi juga memenuhi kaidah pengujian nilai koefisien determinasi $\left(\mathrm{R}^{2}\right)$, yang rata-rata lebih dari 0,987.

\begin{tabular}{|c|c|c|c|c|}
\hline Model & $\mathrm{R}$ & $\begin{array}{c}\mathrm{R} \\
\text { Square }\end{array}$ & $\begin{array}{l}\text { Adjusted R } \\
\text { Square }\end{array}$ & Std. Error of the Estimate \\
\hline 1 &, $994^{\mathrm{a}}$ & -987 & 983 & 608,34903 \\
\hline
\end{tabular}

Hal

ini menunjukkan bahwa variasi variabel independen yang tidak dimasukkan dalam dependen rata-rata mampu dijelaskan model.

lebih dari 98,7\% oleh variabel independen Hasil uji $\mathrm{F}$ secara keseluruhan juga yang dimasukkan dalam model sedangkan menunjukkan bahwa seluruh variabel sisanya dijelaskan oleh variabel yang menyusun model sec ara bersama-sama berpengaruh terhadap variabel dependen pada taraf nyata $1 \%$.

\begin{tabular}{rlrrrrr}
\multicolumn{7}{c}{ ANOVA $^{\text {a }}$} \\
\hline \multicolumn{1}{l}{ Model } & Sum of Squares & df & Mean Square & F & Sig. \\
\hline \multirow{2}{*}{1} & Regression & 713635215,146 & 9 & 79292801,68 & 214,254 & \multirow{2}{*}{, $000^{\text {b }}$} \\
& Residual & 9252213,426 & 25 & 370088,537 & & \\
& Total & 722887428,571 & 34 & & & \\
\hline
\end{tabular}

a. Dependent Variable: Pd

b. Predictors: (Constant), DCC, SP, NPK, Pes, Urea, TK, Pkd, Bn, Lh

Untuk menduga apakah persamaan Suatu persamaan dikatakan tidak ada yang diduga mempunyai masalah masalah autokorelasi jika du $\leq \mathrm{DW} \leq 4$ autokorelasi dapat dilihat dari nilai DW. Nilai dari hasil pendugaan pada Durbin-Watson (DW) yang dihasilkan. model nilai DW adalah 2,143 berarti 
berada pada selang 1.089-2.955, sehingga diduga tidak ada masalah autokorelasi. dapat disimpulkan bahwa pada model

\begin{tabular}{|c|c|c|c|c|}
\hline \multicolumn{4}{|c|}{ Change Statistics } & \multirow[t]{2}{*}{ Durbin-Watson } \\
\hline $\begin{array}{l}\text { R Square } \\
\text { Change }\end{array}$ & F Change & df1 df2 & Sig. F Change & \\
\hline ,987 & 214,254 & 25 & ,000 & 2,143 \\
\hline
\end{tabular}

Pengujian asumsi multikolienaritas <10, sehingga dapat disimpulkan bahwa dilakukan dengan variance inflation factor asumsi non multikolinearitas terpenuhi (VIF). Berdasarkan hasil analisis untuk semua model. diperoleh nilai VIF untuk semua prediktor

\section{Coefficients $^{\mathrm{a}}$}

\begin{tabular}{|c|c|c|c|}
\hline \multirow{2}{*}{\multicolumn{2}{|c|}{ Model }} & \multicolumn{2}{|c|}{ Collinearity Statistics } \\
\hline & & Tolerance & VIF \\
\hline \multirow{10}{*}{1} & (Constant) & & \\
\hline & $\mathrm{Lh}$ & ,012 & 8,766 \\
\hline & $\mathrm{Bn}$ &, 014 & 7,753 \\
\hline & Urea & ,071 & 4,161 \\
\hline & SP & ,686 & 1,458 \\
\hline & NPK & ,477 & 2,096 \\
\hline & Pkd & ,011 & 9,279 \\
\hline & TK & 034 & 9,444 \\
\hline & Pes & ,061 & 6,342 \\
\hline & $\mathrm{DCC}$ & ,303 & 3,301 \\
\hline
\end{tabular}

a. Dependent Variable: Pd

Hasil analisis model fungsi produksi dapat dilihat pada table berikut :

\begin{tabular}{lcr}
\hline \multicolumn{1}{c}{ Variabel } & $\begin{array}{c}\text { Penduga } \\
\text { Parameter }\end{array}$ & Prob T \\
\hline Constanta & $1.462,118$ & 0,008 \\
Luas Lahan (LHN) ${ }^{\mathrm{NS}}$ & 0,092 & 0,789 \\
Benih (Bn)** & 9,716 & 0,000 \\
Urea $\left(\right.$ Urea) $^{* *}$ & 9,191 & 0,002 \\
SP (SP) & 2,271 & 0,267 \\
NPK (NPK) & 2,271 & 0,189 \\
\hline
\end{tabular}




\begin{tabular}{lll}
\hline${\text { Pupuk Kandang }(\mathrm{Pkd})^{\mathrm{NS}}}$ & 0,203 & 0,437 \\
Tenaga Kerja (TK)** & 77,412 & 0,031 \\
Pestisida (Pes)** & $-21,239$ & 0,038 \\
Dummy Penerapan Adaptasi (DCC)** & 126,714 & 0,046 \\
& & \\
Prob F & 0.0001 & \\
F Hitung & 214,254 & \\
Koefisien Determinasi R & 0,987 & \\
\hline
\end{tabular}

Keterangan : NS : tidak nyata pada taraf $95 \%$

** : signifikan pada taraf nyata $95 \%$

Dari hasil analisis regresi variabel independen yang berpengaruh nyata positif adalah Benih, Urea, Tenaga Kerja dan yang berpengaruh nyata negatif adalah Pestisida. Benih signifikan pada taraf $95 \%$ dengan koefisien parameter 9,716 artinya adalah jika benih ditambah 1 $\mathrm{kg}$ maka produksi bertambah sebesar 9,716. Penggunaan benih oleh petani perlu ditingkatkan selain jumlah maupun kualitas. Benih berpengaruh nyata karena penggunaan benih yang baik atau unggul sesuai dengan kebutuhan untuk mengahadapi perubahan iklim sangat dibutuhkan. Urea signifikan pada taraf 95\% dengan koefisien parameter 9,191 artinya adalah jika urea ditambah $1 \mathrm{~kg}$ maka produksi bertambah sebesar 9,191. Urea masih dibutuhkan untuk meningkatkan produksi karena penggunaan rata-rata pupuk masih jauh dari anjuran penggunaan pupuk 300kg/ha yaitu $230 \mathrm{~kg} / \mathrm{Ha}$. Tenaga kerja signifikan pada taraf $95 \%$ dengan koefisien parameter 77,412 artinya adalah jika Tenaga kerja ditambah 1 orang maka produksi bertambah sebesar 77,412. Tenaga kerja yang digunakan oleh petani berasal dari dalam keluarga dan luar keluarga. Tenaga kerja luar keluarga mulai sulit didapatkan karena semakin berkurangnya tenaga kerja dalam sektor pertanian. Oleh karnea itu yang dilakukan petani adalah bergiliran dengan petani lain dalam penggunaan tenaga kerja atau memaksimalkan tenaga kerja dalam keluarga. Dummy penerapan perubahan iklim berpengaruh terhadap peningkatan produksi tanaman, karena semakin baik pengetahuan petani tentang perubahan iklim maka adaptasi yang dilakukan oleh petani sesuai untuk mengurangi dampak perubahan iklim tersebut. Pestisida signifikan pada taraf $95 \%$ dengan 
koefisien parameter $-21,239$ artinya adalah jika pestisida ditambah 1 liter maka produksi berkurang sebesar 21,239. Penggunaan pestisida oleh petani perlu dikurangi kuantitasnya. Dummy penerapan adaptasi signifikan pada taraf 95\% dengan koefisien parameter 126,714 artinya adalah jika Dummy penerapan adaptasi oleh petani berambah $1 \%$, maka produksi bertambah sebesar 126,714 kali.

Lahan tidak signifikan pada taraf 95\% dengan koefisien parameter 0,092 artinya adalah jika lahan ditambah $1 \mathrm{~m}^{2}$ maka produksi tidak berpengaruh pada penambahan produksi. Hal ini dimungkinkan lahan yang dikelola oleh petani belum efisien dalam pemanfaatannya. Masih banyak yang kosong atau belum termanfaatkan dengan baik. SP tidak signifikan pada taraf $95 \%$ dengan koefisien parameter 2,271 artinya adalah jika SP ditambah $1 \mathrm{~kg}$ maka produksi tidak berpengaruh pada penambahan produksi. NPK tidak signifikan pada taraf $95 \%$ dengan koefisien parameter 2,271 artinya adalah jika NPK ditambah $1 \mathrm{~kg}$ maka produksi tidak berpengaruh pada penambahan produksi. Pupuk kandang tidak signifikan pada taraf $95 \%$ dengan koefisien parameter 0,203 artinya adalah jika pupuk kandang ditambah $1 \mathrm{~kg}$ maka produksi tidak berpengaruh pada penambahan produksi.

\section{KESIMPULAN}

Hasil dan pembahasan yang telah diuraikan di atas menghasilkan beberapa kesimpulan antara lain :

1. Hasil identifikasi tindakan atau cara adaptasi terhadap perubahan iklim yang dilakukan oleh petani Tengger secara turun temurun ada 17, antara lain : penggunaan penghematan air, penggunaan pupuk kandang secara intensif, pengolahan lahan berlawanan kontur, penggunaan penutup tanah, penggunaan system irigasi dan drainase yang baik, penggunaan pestisida hayati, peningkatan intensitas penyiangan gulma, penyiapan benih/bibit yang baik dan teliti, penanaman pada awal musim hujan, penanaman tanaman penguat terasiring, penerapan system penanaman tumpang sari/tumpang gilir, perubahan waktu tanam, penggunaan jarak tanam rekomendasi, menghindari penanaman yang sama berturut-turut pada lahan yang sama, mencari informasi tentang perubahan iklim, penanganan hasil panen dengan meminimalkan kehilangan/susut hasil, pengurangan luas lahan. 
Ada 9 tindakan adaptasi yang merupakan rekomendasi dari pihak eksternal antara lain dari pemerintah atau ketua kelompok tani yang sudah berpengalaman. Tindakan adaptasi tersebut antara lain penambahan luas lahan garapan, berpindah dari kegiatan bertani ke kegiatan berdagang, berpindah dari produksi tanaman sayuran ke produksi tanaman pangan atau ternak, lebih giat mencari pekerjaan paruh waktu diluar pertanian, berpindah dari lokasi berisiko tinggi terhadap dampak perubahan iklim, pengurangan penggunaan input kimiawi, penggunaan pestisida kimia, penggunaan varietas tahan hama penyakit, dan penggunaan varietas tahan hujan/kekeringan.

2. Hasil analisis regresi variabel independen yang berpengaruh nyata positif adalah Benih, Urea, Tenaga Kerja dan yang berpengaruh nyata negatif adalah Pestisida. Benih signifikan pada taraf $95 \%$ dengan koefisien parameter 9,716 artinya adalah jika benih ditambah $1 \mathrm{~kg}$ maka produksi bertambah sebesar 9,716. Penggunaan benih oleh petani perlu ditingkatkan selain jumlah maupun kualitas. Benih berpengaruh nyata karena penggunaan benih yang baik atau unggul sesuai dengan kebutuhan untuk mengahadapi perubahan iklim sangat dibutuhkan. Urea signifikan pada taraf $95 \%$ dengan koefisien parameter 9,191 artinya adalah jika urea ditambah $1 \mathrm{~kg}$ maka produksi bertambah sebesar 9,191. Pupuk urea masih dibutuhkan untuk meningkatkan produksi karena penggunaan rata-rata pupuk masih jauh dari anjuran penggunaan pupuk $300 \mathrm{~kg} /$ ha yaitu 230 $\mathrm{kg} / \mathrm{Ha}$. Tenaga kerja signifikan pada taraf $95 \%$ dengan koefisien parameter 77,412 artinya adalah jika Tenaga kerja ditambah 1 orang maka produksi bertambah sebesar 77,412. Tenaga kerja yang digunakan oleh petani berasal dari dalam keluarga dan luar keluarga. Tenaga kerja luar keluarga mulai sulit didapatkan karena semakin berkurangnya tenaga kerja dalam sektor pertanian. Oleh karnea itu yang dilakukan petani adalah bergiliran dengan petani lain dalam penggunaan tenaga kerja atau memaksimalkan tenaga kerja dalam keluarga. Dummy penerapan perubahan iklim berpengaruh terhadap peningkatan produksi tanaman, karena semakin baik pengetahuan petani tentang perubahan iklim maka adaptasi yang 
dilakukan oleh petani sesuai untuk mengurangi dampak perubahan iklim tersebut. Pestisida signifikan pada taraf 95\% dengan koefisien parameter $-21,239$ artinya adalah jika pestisida ditambah 1 liter maka produksi berkurang sebesar 21,239. Penggunaan pestisida oleh petani perlu dikurangi kuantitasnya. Dummy penerapan adaptasi signifikan pada taraf $95 \%$ dengan koefisien parameter 126,714 artinya adalah jika Dummy penerapan adaptasi oleh petani bertambah $1 \%$, maka produksi bertambah sebesar 126,714 kali.

Lahan tidak signifikan pada taraf 95\% dengan koefisien parameter 0,092 artinya adalah jika lahan ditambah $1 \mathrm{~m}^{2}$ maka produksi tidak berpengaruh pada penambahan lahan. Hal ini dimungkinkan lahan yang dikelola oleh petani belum efisien dalam pemanfaatannya. Masih banyak yang kosong atau belum termanfaatkan dengan baik. SP tidak signifikan pada taraf $95 \%$ dengan koefisien parameter 2,271 artinya adalah jika SP ditambah $1 \mathrm{~kg}$ maka produksi tidak berpengaruh pada penambahan produksi. NPK tidak signifikan pada taraf $95 \%$ dengan koefisien parameter 2,271 artinya adalah jika NPK ditambah $1 \mathrm{~kg}$ maka produksi tidak berpengaruh pada penambahan produksi. Pupuk kandang tidak signifikan pada taraf 95\% dengan koefisien parameter 0,203 artinya adalah jika pupuk kandang ditambah $1 \mathrm{~kg}$ maka produksi tidak berpengaruh pada penambahan produksi.

\section{SARAN}

Berdasarkan hasil penelitian, sekiranya peneliti dapat mengajukan beberapa saran bagi petani di daerah penelitian sehingga nantinya diharapkan efisiensi teknis usahatani kentang dapat tercapai di daerah penelitian.

1. Petani harus terus menambah pengetahuan dan ketrampilannya dalam perubahan iklim guna peningkatan produksi usahataninya

2. Dalam meningkatkan produksi tanaman kentang di daerah penelitian petani harus memperhatikan dosis anjuran dalam penggunaan faktor produksi.

3. Petani dapat mengurangi penggunaan pestisida kimia dengan penggunaan pestisida hayati untuk meningkatkan produksinya, karena penggunaan pestisida kimia sudah memasuki 
tahap berlebih dan akan mengurangi hasil produksi.

4. Dalam meningkatkan produksi tanaman kentang diperlukan berbagai pengetahuan, pengalaman, dan ketrampilan dalam mengkombinasikan input produksi.

\section{DAFTAR PUSTAKA}

Hatfield, J. L.; Boote, K. J.; Kimball, B. A.; Ziska, L.H.; Izaurralde, R.C.;Ort, D.;Thomson, A. M.; and $\mathrm{W}$ olfe, D., "Climate Impacts on Agriculture:Implications for Crop Production" (2011). Publications from USDA-ARS /UNL Faculty. Paper 1350

IPCC. (2013). Climate Change 2013: The Physical Science Basis. Contribution of Working Group I to the Fifth Assessment Report of the Intergovernmental Panel on Climate Change. Cambridge University Press, Cambridge, United Kingdom and New York, NY, USA.

Nurrahim, A. (2014). Dinamika Kearifan Tradisional Masyarakat Desa Ranu Pane Dalam Pemanfaatan Sumberdaya Hayati Di Taman Nasional Bromo Tengger Semeru. Skripsi Fakultas Kehutanan Institut Pertanian Bogor.

Otitoju, MA, Enete, AA. (2014). Climate Change Adaptation Strategies and Farmlevel Efficiency in Food Crop Production in Southwestern, Nigeria TROPICULTURA, 2014, 32, 3, 113120

Salinger, M. J, Stigter, C. J, Das HP. (2000). Agrometeorological adaptation strategies to increasing climate variability and climate change. Agric For Meteorol 103(12):167-184

Salwati. (2012). Aplikasi Model Simulasi Untuk Prediksi Dampak Perubahan Iklim Terhadap Produktivitas Tanaman Kentang (Solunum toberosum L) di Indonesia. Desertasi Pascasarjana Institut Pertanian Bogor. Bogor.

Sulistiono R dan Sumarno. (2011). Perubahan Iklim Global. PPSUB Malang. USBN :978-602-8624-32-9

Wang, J. Huang, J. Rozelle, S. (2010). Climate Change and China's Agricultural Sector: An Overview of Impacts, Adaptation and Mitigation. International Centre for Trade and Sustainable Development (ICTSD) International Envrionment House 2. Geneva, Switzerland

Watson, R. T., Zinyowera, M. C., \& Moss, R. H. (1996). Climate change 1995. Impacts, adaptations and mitigation of climate change: scientific-technical analyses. 